\title{
Congress, the media and interest groups
}

Any dictator would admire the uniformity and obedience of the U.S. media. (Noam Chomsky)

In the previous chapters, the relationship between the voters, parties, the President and members of Congress have been examined. This section looks at two other actors who impact on Congress: the media and interest groups.

\section{Media}

The media performs a crucial role in the American political process. The majority of voters will have little or no personal contact with Congress or its members. These voters rely heavily on newspapers, radio, television and the Internet for information about their elected representatives. This position gives the media the potential to influence the political agenda of the nation greatly. It also has opened up the media to accusations that it is not living up to its responsibilities.

\section{Development of the modern media}

In a country the size of the United States, the media has always had an important role to play in relaying information about 
the federal government to citizens across the nation. From the beginning of the republic until the twentieth century this role was the sole preserve of newspapers.

Newspapers in the United States are generally local concerns. In the early years of America this was a matter of practicality; the technology to distribute a daily newspaper across the whole nation was not available. Today, while one major national newspaper, USA Today, exists, locally produced broadsheets are still the norm. The most influential of newspapers, the New York Times and the Washington Post are still locally based.

As the twentieth century progressed, radio and television began to challenge the dominance of the printed word. These new mediums could respond quicker than newspapers and were often seen as being more politically neutral. Especially in the eighteenth century, newspapers were often openly partisan. The political establishment was quick to adapt to the development of the new media. President Franklin D. Roosevelt used radio to deliver his 'fireside chats' to the American public. John F. Kennedy, the first 'television President' used his good looks and easy manner to deliver his messages directly into the homes of the people. Still today, the President will deliver a weekly radio address on any subject of his choice and will on important occasions address the nation via television.

Newspapers still have an important role to play. They have retained the ability to pursue stories over a longer period of time and to undertake in-depth investigations, free from the pressures suffered by television and radio to report news on an hourly basis. The most famous of these investigations was the Watergate affair which, ultimately, led to the resignation of President Richard Nixon. The central figures behind reveal- 
ing the scandal and the cover-up which followed were two reporters from the Washington Post, Carl Bernstein and Bob Woodward. Their efforts led to the award of a Pulitzer Prize and were immortalised in the film All the President's Men starring Robert Redford and Dustin Hoffman.

\section{Entertainment $v$. information}

The main criticism which has been levelled at the media is that there exists a conflict between providing entertainment and providing serious news, and that this conflict has led to the media, especially television, trivialising politics. Television is now the main source of news for the vast majority of the American public. Television companies are businesses which rely on advertising revenue to make a profit. In order to attract and retain advertisers, stations must keep people watching their shows. The need to entertain has become paramount.

It has been argued that the pressure to attract viewers has had two effects on television coverage of politics. The first effect is to shorten the amount of time spent on news stories. To avoid any danger of boring the audience into switching channels, news programmes have become fast moving, favouring short news items rather than detailed investigations and reliant on 'soundbites' over more in-depth interviews. Even the most complex of issues must be condensed into a few minutes to ensure the continued attention of the audience. The average length of a soundbite on American television during presidential election campaigns has shrunk from 43.1 seconds in 1968 to 8.2 seconds in $1996 .{ }^{1}$ Noam Chomsky, a critic of media coverage of politics, quotes a source from ABC's Nightline (one of the more serious and respected news programmes), who described the ideal guest on the programme as 
someone who can restrict their answers to 30 seconds or less. It is easy to argue that such limitations make it impossible to investigate or explain complex political issues without gross oversimplification.

The second effect of the conflict between entertainment and news is the trivialising of political coverage. Television has been accused of focusing on sensational, salacious or trivial stories under the guise of news reports which reduce politics to a series of scandals, gaffes and personality issues. In 2001, Congressman Gary Condit of California found himself in the glare of the media spotlight. Condit, a conservative Democrat, was widely considered to be a rising star in Washington DC politics. He was willing to work with both Republicans and Democrats and with the House of Representatives closely divided between Democrats and Republicans following the 2000 election, members such as Condit became crucial in the battle for votes. It was no surprise when he was invited to join the Democrat leadership council. For all of Condit's political achievements and his growing importance in Congress, few outside of California's 18th district would probably have heard of Gary Condit. On 30 April 2001 Chandra Levy, who had been working for Congressman Condit as an intern, disappeared. As fears grew for her safety, it became known that Levy had been having an affair with the Congressman. Condit was far from open about his relationship with Chandra Levy and was accused by the police of being obstructive to their investigation. Police investigators removed items from his home and soon rumours circulated regarding any role Condit might have had in Levy's disappearance. Despite police statements insisting that Condit was not being investigated in any way in relation to Levy's actual disappearance, the damage to the Congressman had been done. 
In March 2002 he was defeated in the Democrat primary for his district, a seat which he had held so comfortably in previous elections that he had started giving some of his campaign funds to charity.

The case against the media has merit; however there is also a good case for the defence. While television news programmes have a duty to report the issues of the day, they also must present them in a way which is accessible and interesting to the general public. If they did not do this, the public would get quickly bored and not watch the news at all. For those with a desire to see a more in-depth analysis of politics, coverage is available. CSPAN, for instance, broadcasts live sessions of Congress and reports on Congressional politics. Programmes such as Nightline, Meet the Press and Face the Nation provide a more detailed coverage of issues than the regular news programmes. Newspapers such as the New York Times and the Washington Post also provide a good level of political analysis. It can be argued that, while the media is guilty of sensationalism, in the case of Gary Condit, they pursued a valid story. While such scandals have nothing to do with the policies members of Congress advocate, they point to flaws in character and judgement. Candidates for Congress often make great of their strength of character in an attempt to win votes and once elected need to be trusted to use their judgement to the benefit of their constituents and the nation as a whole.

\section{Interest groups}

Interest groups (or pressure groups) are groups of individuals or organisations who band together in order to promote or defend their shared interests. The American political system 
provides numerous access points for anyone looking to influence policy. Groups can approach individual members of Congress, Congressional committees and staff, executive branch departments and agencies along with numerous state and local government institutions. The strategies groups use to influence Congress vary depending on their size and resources.

\section{Insider strategies}

Insider strategies involve direct contact between interest groups and members of Congress (or their staff). Those groups with sufficient resources will hire professional lobbying firms to contact lawmakers on their behalf. Professional lobbyists will have expert knowledge of how the legislative process works and who the key players are for any issue and will have developed relationships with members of Congress over time. Many lobbyists are former members of Congress or Congressional staffers. Worried about conflicts of interests, there is a legal 'cooling off period' which prevents Representatives and Senators from moving immediately from elected office to a lobbying firm. Small interest groups lobbying on their own can often find problems in gaining access to members, especially on major issues where there are many groups competing for their time. Groups can start to overcome this problem by establishing offices in Washington DC and building relationships over a period of time.

One of the biggest advantages interest groups hold is their knowledge of the issues they are concerned with. This expertise can be used in a number of ways: to try and persuade a member to vote in the required direction, to supply sympathetic members with evidence or arguments to use in support of their view, or to testify in front of a committee hearing. 
Committee hearings are the most high profile of arenas where groups can put their arguments to Congress. There is some doubt, however, as to whether evidence put to the committee can actually change the minds of long-standing committee members. This was considered in chapter 3 .

The most controversial aspect of interest groups' activities is the money donated to the campaign funds of sitting and prospective members of Congress. As discussed in chapter 2, despite interest groups being restricted by the Federal Election Campaign Act to donations of $\$ 5,000$ per candidate per election, the amount of money received by all candidates has risen dramatically since the 1970s. In addition the rise in so-called 'soft money' donations to local political parties have increased interest groups' financial investment in the electoral process. The fear expressed by campaigning groups such as Common Cause and The Center for Responsive Politics is that a political system awash with financial contributions from businesses groups and other interests opens itself to the danger of corruption (see Appendix).

The loophole of soft money was finally regulated in 2002 when a bill co-sponsored by Republican Senator John McCain of Arizona passed Congress after a long struggle. McCain, had consistently advocated campaign finance reform after being caught in a scandal involving donations. In 1989, five Senators were accused of attempting to interfere with an investigation into the collapse of a Savings and Loan company owned by Charles Keating. It emerged that Keating, in total, had donated over $\$ 1$ million to those Senators' campaign funds. After a lengthy investigation, the Senate criticised four of the Senators for poor judgement and reprimanded one, Senator Alan Cranston of California for 'improper and repugnant' conduct. The Senate concluded that Senators John 
McCain and John Glenn had not been extensively involved.

This was not the first time the US Congress had been hit by scandal involving money. In 1980, in the 'ABSCAM' scandal, an FBI undercover operation brought charges of bribery against six Representatives and one Senator. All either resigned their seats or were defeated in the next election, except Congressman Michael J. 'Ozzie' Myers who was expelled from the House. In 1997 House Speaker Newt Gingrich was fined over $\$ 30,000$ following charges of ethics violations and misleading the House over his use of funds from a non-profit organisation for political purposes. The scandal contributed to his early retirement from Speakership and ultimately from the House. The irony in the Gingrich scandal was that, in 1989, he had been at the forefront of a campaign which led to the resignation of Speaker Jim Wright following allegations of misuse of funds from book royalties.

For the most part, however, donations from interest groups are open and made within the law. Whether donations can 'buy' a member's vote is open for debate. While a donation of $\$ 5,000$ is no small amount, it is only a fraction of the average total raised by members of Congress, especially for those running for the Senate. The first consideration of any member when deciding how to act or cast a vote will be the possible reaction of their constituents. In most circumstances, no amount of money from an interest group will persuade a member to vote or act in a way that would jeopardise their reelection. However, on issues which are not high profile, or which constituents have little interest in, there remains a question of to what extent money can sway votes. Academic studies do not agree; some suggest a link between donations and votes, others argue that no link exists at all.

In the majority of cases, however, money is not spent in an 
attempt to change the view of members of Congress, instead it tends to flow from interest groups to members who are already sympathetic to their position. With this, groups are trying to achieve two things. Firstly, by donating money to the election campaigns of candidates who support their position, groups hope to facilitate the election of members sympathetic to their cause. Secondly, if that member is returned to Congress, groups hope that their financial investment will result in improved access. Donations are normally used as part of a wider lobbying strategy, with the money being used to increase the effectiveness of a group's arguments and persuasion.

For most groups, the money available for political donations is limited. This means that targeting the right members is crucial if the money is to be used effectively. It will be of little use to a group if their campaign contributions find their way to members who are publicly opposed to that group's point of view. Funds will also not be used efficiently if given to members who are unable or unwilling to make an impact in Congress on the donating group's key issue. Consequently, groups will often target members of Congress who sit on a committee with jurisdiction over the issue, especially those who have a track record of activity in the area of concern

\section{Outsider strategies}

Outsider strategies are those which groups use to put pressure on Congress and its members without working directly in Capitol Hill itself. Such strategies look to mobilise and demonstrate public support around their issue. The aim of outsider action is to suggest to members of Congress that their stand on the issue may have electoral consequences. Examples of such strategies can include organising demonstrations, letter writing campaigns or advertising in the media. 
There is some question to how effective outsider strategies are in influencing the legislative process. It is argued that groups resort to such activities when, unlike, say, business groups, they do not have the resources or contacts to effectively lobby from within Congress. On Mothers' Day 2000, one of the largest public protests America had seen took place under the name 'The Million Mom March'. The March was a protest against gun violence and for legal controls on the possession of firearms. Over 750,000 people marched on the National Mall in Washington DC. Thousands also joined marches in towns and cities across the country. The demonstrations achieved maximum publicity for the cause of gun control, but had very little impact in terms of new legislation.

However, this assessment is not entirely fair. Research by Kay Schlozman and John Tierney suggests that rather than a last resort, public activity is the norm for a majority of interest groups. They estimated that over 80 per cent of groups engaged in grassroots lobbying and letter- writing campaigns, and one-third of groups placed adverts in the media. ${ }^{2}$ These efforts are often used to supplement more direct lobbying. While change may not be achieved immediately, public campaigns can have the effect of keeping an issue on the political agenda. Throughout the 1950s and 1960s, civil rights demonstrations led by interest groups such as the National Association for the Advancement of Colored People (NAACP) made a huge impact on the national political scene. Television pictures of the brutality which occasionally greeted the marchers highlighted the issue further. These public displays were central to the debate which eventually led to the passage of the 1964 Civil Rights Act.

For most groups, such mass action is impossible to organise. Letter-writing campaigns or marches will be much more 
low key. The success of small group action will depend on how effectively they can target individual constituencies of members.

\section{Is there a level playing field?}

All interest groups are not equal; inevitably some will have larger financial resources, others will have greater public support. However, one question which has long been debated is that if a group is sufficiently resourced and organised to lobby Congress, will they find a level playing field? The arguments on this matter can be characterised by two extremes pluralism and elite theory.

Pluralist group theory, expounded by such writers as Arthur Bentley and David Truman, views government as a neutral arbiter of competing interests. ${ }^{3}$ Government has no preconceived position on any issue, but instead acts as the venue where interest groups can compete to influence policy. In the case of Congress, it will be the committees which provide the focus for competition between interests. Under the pluralist model, as problems arise, groups will mobilise in response. As one interest gets their way in terms of policy, others will mobilise in opposition, forming what are known as policy subsystems. If there is significant support for a point of view, this will be represented at government level. In this way, the battle between organised interests is a dynamic one which shifts and changes with political and social developments. An often quoted example of such mobilisation is the rise of the labour movement during the 1930s in response to hardships brought on by the Great Depression.

At the other end of the theoretic spectrum is elite theory. Under this model, government is a vested interest in itself, rather than some sort of neutral arbiter. Government is populated by 
types of people with similar backgrounds, views and values. A leading elite theorist, C. Wright Mills, writing in 1956, described those elected to Congress thus

as social types ... [they] are not representative of the rank and file citizens. They represent those who have been successful in entrepreneurial and professional endeavours. Older men, they are of the privileged white, native-born of native parents, Protestant Americans. They are college graduates and they are at least solid, upper-middle class in income and status. On average, they have had no experience of wage or lower salaried work. They are, in short, in and of the new and old upper classes of local society. ${ }^{4}$

As discussed in chapter 2, the background of members of Congress had become more diverse since Mills was writing. However, the accusation still remains that Washington establishment is still dominated by a business-oriented upper class and their shared attitudes set the parameters for debate. Accordingly, groups representing big business will have a huge advantage over public interests. They will have greater contacts throughout Washington DC, better resources and share the beliefs and goals of most members of Congress.

One variant of elite theory is that which suggests that the policy process is dominated by iron triangles (briefly discussed in chapter 4). The three points of the triangle are the Congressional committee with jurisdiction over an issue, the department or agency with responsibility for executing the law and certain interested groups. The argument runs that each part of the triangle reaches consensus on the direction of policy and because of the dominance of the committee over the legislative process, dissenting voices are not allowed in. The most famous case of an iron triangle was suggested by President Eisenhower in his farewell speech, when he warned 
of the dangers of the 'military-industrial complex'. In this example, it is the Armed Services Committee of Congress (the members of which will often represent constituencies where the military is a major employer), the department of defense (or Pentagon) and groups such as arms manufacturers. All parts of this triangle have an interest in increasing spending on defense and have the ability to dominate the policy process, regardless of the impact of the policy on the economy or society as a whole.

Since the Republican Party took control of Congress in 1995, there have been accusations that business groups and others have received unprecedented access to the legislative process. The accusations were particularly directed at policy making on environmental and energy issues. Environmental groups complained that the very companies who were subject to environmental laws made by Congress were allowed to work closely with the Republican majority to rewrite legislation. One Republican Congressional aide admitted there was some truth to this, but argued that there was no conspiracy at work,

[Environmental groups] brought that up as an issue and I think that is a bogus issue. They work with Democrats; Democrats are their allies and the environmentalists work very hard to get ... Democrats elected. It should be no surprise that when the Democrats are writing a bill they would call in their friends and when the Republicans are writing a bill they are going to call in their friends. We [Republicans] talked to the environmentalists, they testified before our committees in, I think, fairly balanced hearings. But it shouldn't surprise anyone, unless they are really naive, that Republicans would be a little more solicitous of farmers' concerns or some business concerns. That is what the whole election is about. ${ }^{5}$ 
The reality of Congressional-interest group relations probably falls somewhere between the pluralist and elite models. The idea of iron triangles must be disputed. Hugh Heclo has argued that such tight 'subgovernments' have proved very difficult to maintain, and instead he suggests that more diverse issue networks have arisen. He accepts that certain groups with expert knowledge and shared values will work closely with committees and bureaucrats, but that the large number of participants will prevent any permanent consensus being reached.

While big business will have a major advantage in lobbying Congress through its resources, expertise and relationships in government, this does not mean that public-interest groups are doomed to failure. Ralph Nader, who ran as a Green Partry candidate for the presidency in 1996 and 2000, has shown how a public campaigner can have an effect. In 1965, Nader published a book entitled Unsafe at any speed, which exposed the poor safety standards which he claimed existed throughout the American car industry. Nader's campaign was highly influential in the passage of the 1966 National Traffic and Motor Vehicle Safety Act. Nader went on to lead campaigns on food safety and environmental issues. However, it can be argued that such success stories are the exception and that in the day-to-day business of lawmaking, small public-interest groups will struggle to make a major impact.

\section{Summary}

Media and interest groups have an impact on Congress. The media will influence how Congress is perceived by the public. The growth of television has led to accusations that the media, 
in search of entertainment and viewing figures, has trivialised politics, focusing on sensation rather than news. Interest groups try to influence Congress in a number of ways. Their tactics can be divided into outsider and insider strategies. The most controversial of strategies is the donation of money to members' campaigns. This has led to accusations of corruption, although the evidence for how far money can 'buy' votes is mixed. What is also of concern is that it can be argued that only the biggest and richest groups have a significant effect on the legislative process.

\section{Appendix: top gun}

In its bid to quash legislation that would respond to a rash of school shootings by strengthening the nation's gun laws, the National Rifle Association (NRA) outspent gun control advocates nearly 50-1 in campaign contributions to members of Congress in the first half of 1999. Newly filed records with the Federal Election Commission show the NRA contributed more than $\$ 270,000$ from its political action committee to members of Congress between Jan. 1 and July 31, 1999, 81 percent to Republicans. During the same period, Handgun Control, a leading advocate for new gun laws, made $\$ 5,500$ in PAC contributions, all to Democrats.

Such spending came during a period when Congress was wrestling with proposed legislation that included stronger regulations on gun shows and measures that would determine whether gun manufacturers could be held liable for damage caused by guns. The most contentious debate emerged after a spate of deadly school shootings, including the April massacre of 14 students and a teacher at Colorado's Columbine High School. Lawmakers, propelled by outrage over Columbine and rising gun violence, introduced several measures, including amendments to limit the number of handguns that a household could purchase each month.

Analysis of the NRA's political giving shows contributions to lawmakers were made alongside key events during the gun-control 
debate. During May, the NRA PAC contributed \$23,550 to lawmakers, almost all of which was given on May 6 - the same day Senate Democrats unveiled what would be the first of numerous gun-control policy packages on Capitol Hill. Among the recipients was Sen. Slate Gorton (R-Wash.), who received \$1,000. Gorton is a longtime critic of proposed gun curbs, who would emerge as a prominent supporter of the NRA in the recent debate. 'We all know that there is no effective legislation we could pass that would comply with the First Amendment' Gorton told the Christian Science Monitor on May 6.

In a major defeat for the NRA just days later, the Senate narrowly rejected, then approved, a juvenile-justice bill that included controls on the import of gun ammunition as well as a mandatory three-business day check on the buyers of weapons sold at gun shows. The bill's passage marked the first time in more than five years that lawmakers had approved substantial gun-control legislation. In June, as the House prepared to take up its own version of the gun bill, the NRA nearly quadrupled its contributions to lawmakers. The NRA PAC reported giving $\$ 88,500$ to lawmakers that month, with more than $\$ 80,000$ going to House members. Seventyfour percent of the NRA contributions in June went to House Republicans.

On June 7, House Democrats and Republicans began crafting separate versions of a juvenile-justice bill that would be introduced later in the week. That same day, the NRA contributed $\$ 31,700$ to lawmakers, including \$1,000 to Rep. John Dingell (D-Mich.) and $\$ 2,500$ to Rep. Bud Cramer (D-Ala.), two prominent Democrats who would join the Republicans in defeating the gun bill. Dingell, during the House debate, sponsored an amendment that would limit background checks at gun shows to 24 hours, after which the weapon could be sold to the buyer whether or not the check had been completed. Later, he urged conservative Democrats to vote against the entire gun bill, even though his amendment had been approved. 'There are sensible ways to ensure law-abiding citizens' rights to purchase firearms while forever closing the gun-show loophole,' Dingell told The Washington Times.

Gun control advocates, who viewed the House juvenile justice 
bill as too weak, united on June 17 with gun rights proponents, who viewed the bill as too strong, to defeat the measure. Within a week, the NRA gave $\$ 52,800$ to lawmakers, nearly $\$ 16,000$ of which went to House Democrats who voted against new gun curbs.

By Holly Bailey

Reproduced with the permission of The Center for Responsive Politics (www.opensecrets.org).

\section{Notes}

1 Center For Media And Public Affairs.

2 K. L. Schlozmand and J. T. Tierney, Organized Interests and American Democracy (New York: Harper \& Row, 1986), p. 150.

3 A. Bentley, The Process of Government (San Antonio: Trinity University Press, 1949); D. B. Truman, The Governmental Process (New York: Alfred Knopf, 1951).

4 C. W. Mills, The Power Elite (Oxford: Oxford University Press, 1956), p. 248.

5 Interview conducted by author, 16/5/96, Washington DC. 